\title{
Factors Associated with Childhood Tonsillitis in Somalia
}

\author{
Abdulkadir Mohamed Muse ${ }^{1}$, Abdiwahab Mohamed Hassan ${ }^{1}$, Gallad Dahir Hassan ${ }^{2}$ \\ ${ }^{1}$ Programs, Somali Institute of Development and Research Analysis (SIDRA), Garowe, Puntland, Somalia \\ ${ }^{2}$ Department of Public Health, College of Medicine and Health Science, Jamhuriya University of Science and Technology, Mogadishu, \\ Somalia
}

\author{
Email address: \\ abdulkadir.mm@sidrainstitute.org (A. M. Muse)
}

\section{To cite this article:}

Abdulkadir Mohamed Muse, Abdiwahab Mohamed Hassan, Gallad Dahir Hassan. Factors Associated with Childhood Tonsillitis in Somalia. American Journal of Pediatrics. Vol. 7, No. 1, 2021, pp. 23-27. doi: 10.11648/j.ajp.20210701.16

Received: February 17, 2021; Accepted: March 1, 2021; Published: March 10, 2021

\begin{abstract}
Background: Tonsillitis, acute or chronic, is more common among children than adults. Risk factors associated with the occurrence of tonsillitis among Somali children are not well-defined mainly due to lack of health research in Somalia. The purpose of this study is to identify the main risk factors of childhood tonsillitis to better prevent and avoid further complications of the disease. Methods: The study included the caregivers of 60 children with tonsillitis receiving treatment, at the time of the study, from Garowe General Hospital. A convenience sampling method was used and data were entered into SPSS and analyzed for frequency and percentages. Results: This study shows that the majority of the study participants with tonsillitis $32(53 \%)$ were $1-7$ years old and $39(65 \%)$ of the participants were female. Childhood tonsillitis was associated with parents' lower educational levels: illiterate $32(53.3 \%)$, primary education $20(33.3 \%)$, secondary school 6 (10\%), and university level $2(3.3 \%)$. The importance of personal hygiene was believed in by $31(52 \%)$ of the caregivers, while $18(17 \%)$ of the caregivers reported that their children do not brush their teeth at all. The majority of the caregivers $50(83 \%)$ believed that tonsillitis is a disease with less severity. A family history of tonsillitis $49(82 \%)$ was also associated with childhood tonsillitis. Conclusion: Low socioeconomic status, family history of tonsillitis, and poor personal hygiene were all associated with childhood tonsillitis. Furthermore, in addition to tonsillitis, some of the children in this study had malnutrition, asthma, and allergies. To successfully prevent and control childhood tonsillitis, identification of its risk factors is crucial.
\end{abstract}

Keywords: Childhood Tonsillitis, Risk Factors, Socioeconomic Status, Somalia, Chronic Tonsillitis

\section{Background}

Anatomically, the tonsils are two glands in the posterior of the oropharynx. They are part of the body's defense system upon the antigen's entry through the nasal or oral cavities [13]. Tonsillitis is the bacterial or viral inflammation of the tonsils. This disease manifests in two forms: acute and chronic, however, the literature has various terminologies for tonsillitis [3].

Acute tonsillitis is an episode of tonsillitis lasting for a shorter period of time and "refers to viral or bacterial tonsillitis with odynophagia, swelling, and redness of tonsils, possibly with tonsillar exudate, cervical lymphadenopathy, and fever" [3]. On the other hand, chronic tonsillitis is a recurring inflammation of the tonsils with a number of episodes per year which could lead to tonsillectomy [1-4].

Tonsillitis affects more children than adults around the world with more chronic and recurrent infections during childhood [1, $3,4]$. In a single year, a child may get a sore throat 7 sore throat episodes [5]. Currently, there is not enough data on the global incidence of tonsillitis [4]. However, in primary care, sore throat makes up to $1.3 \%$ of outpatient visits $[6,7]$. Studies have shown that there is a gender difference in the occurrence of tonsillitis with more recurrent tonsillitis in females and more peritonsillar abscesses in males [8]

Although studies on genetic and environmental predisposing factors for tonsillitis are limited, some studies have established the possibility of the heritability of recurrent tonsillitis [9]. Studies have also suggested that poor living conditions and indoor pollution could exacerbate sore throat risk factors [5].

Unfortunately, with long-lasted instability, lack of holistic health research, and insufficient health records [10, 11], there is no sufficient data on the morbidity of tonsillitis in Somalia. Socioeconomic factors affect the health of children, especially in 
developing countries where nutrition, personal hygiene, family income, and health services accessibility and utilization, all significantly impact children's health status [12-15].

The aim of this study is to identify and assess the risk factors associated with childhood tonsillitis in Somalia. To our knowledge, this is the first study conducted on the risk factors of childhood tonsillitis in Puntland, Somalia.

\section{Methods}

This study was conducted in Garowe General Hospital, 2020. Garowe is the capital city of the Nugal region, Puntland, Somalia. This study utilized a descriptive cross-sectional design. The aim of this study was to epidemiologically assess the risk factors associated with childhood tonsillitis. Garowe General Hospital is a regional hospital providing health services for residents of the Nugal region as well as residents from neighboring regions of Puntland. Therefore, this hospital is optimal for the purpose of this study.

This study included caregivers of children (under the age of 15) diagnosed with tonsillitis, and, at the time of the study, receiving treatment in Garowe General hospital. A convenient sample of 60 caregivers was selected for this study. A convenient sampling technique was utilized which satisfies the goal of this study as well as the accessibility of the study population. A close-ended questionnaire was used to collect data from the study participants. The data collected and generated by the study were analyzed using the Statistical Package for Social Sciences (SPSS) to obtain the percentages and frequencies of data.

\section{Results}

The majority of the study participants with tonsillitis (53\%) were 1-7 years old. In this study, $39(65 \%)$ of the participants were female and $21(35 \%)$ were male. The educational levels of the caregivers in this study were: illiterate $32(53.3 \%)$, primary education $20(33.3 \%)$, secondary school $6(10 \%)$, and university level $2(3.3 \%) .55 \%$ of the caregivers were homemakers, $20 \%$ were employed, and $25 \%$ were business owners or self-employed. The study shows that $35 \%$ of the families had a monthly income of over 200 dollars, $57 \%$ of them reported an income of 100-200 dollars, and $8 \%$ of them reported an income of less than a 100 dollars. The study also shows that $36(60 \%)$ of the affected children were from larger families (4 to 5 members)Approximately, 31 (52\%) of the caregivers in this study understood that personal hygiene is essential in disease prevention in general, and in tonsillitis, specifically. in addition, $31(52 \%)$ of the children in this study brush their teeth only once a day, 12 (20\%) of them do it twice a day, only $6(10 \%)$ do it three times a day, and 18 $(17 \%)$ of the study participants do not brush their teeth at all.

Furthermore, the study found that 40 (67\%) of the caregivers held the belief that consuming cold drinks in excess by the children could potentially cause or lead to tonsillitis. Also, poor hygiene 16 (27\%), malnutrition 4 (7\%), and weather change $10(16 \%)$ were all considered causes or main contributors to childhood tonsillitis by the caregivers. When asked about whether tonsillitis is a severe disease, 50 $(83 \%)$ of the caregivers answered that tonsillitis is less severe, and only $10(17 \%)$ of them saw tonsillitis as a potentially severe disease with complications.

A family history of tonsillitis was reported by 49 (82\%) of the study participants. Comorbidity of tonsillitis with malnutrition $(10 \%)$, asthma (5\%), and allergies (7\%) were also reported by the participants. The study also found that $39(65 \%)$ of the children had chronic rhinitis and chronic sinusitis. Moreover, the children in this study had adenoid hypertrophy and nasopharyngitis $47(78 \%)$, peritonsillar abscess (48\%), emesis/hemorrhage 50 (83\%), other upper respiratory infections, and $45(75 \%)$ of them were mouth breathers. Only $18(30 \%)$ of the caregivers believed that their children were receiving adequate treatment for tonsillitis.

Table 1. Socio-demographic Variables.

\begin{tabular}{llll}
\hline Variable & & Frequency & Percentage (\%) \\
\hline \multirow{2}{*}{ Child Gender } & Male & 21 & 35 \\
& Female & 39 & 65 \\
Age of & $<1$ year & 5 & 8 \\
Respondents & 1-7 year & 32 & 53 \\
& 8-15 Year & 23 & 38 \\
Mother's & Illiterate & 32 & 53.3 \\
Education & Primary School & 20 & 33.3 \\
& Secondary School & 6 & 10 \\
Mother's & University & 2 & 3.3 \\
Occupation & Employed & 12 & 20 \\
& Self-employed & 15 & 25 \\
Family size & House-wife & 33 & 55 \\
& 3 or fewer & 10 & 17 \\
& $4-5$ & 36 & 60 \\
Family income & $>5$ & 14 & 23 \\
in dollar & $100-200$ & 5 & 8 \\
& $>200$ & 21 & 35 \\
\hline
\end{tabular}

Table 2. Caregivers' $K A P$ of tonsillitis.

\begin{tabular}{|c|c|c|c|c|}
\hline Variable & & & Frequency & $\begin{array}{l}\text { Percentage } \\
(\%)\end{array}$ \\
\hline \multirow{3}{*}{$\begin{array}{l}\text { Believe in the } \\
\text { effectiveness of } \\
\text { hygiene in } \\
\text { preventing tonsillitis }\end{array}$} & \multicolumn{2}{|l|}{ Yes } & 31 & 52 \\
\hline & \multicolumn{2}{|l|}{ No } & 29 & 48 \\
\hline & \multicolumn{2}{|l|}{ Not at all } & 11 & 18 \\
\hline \multirow{3}{*}{$\begin{array}{l}\text { Frequency of teeth } \\
\text { brush per day }\end{array}$} & \multicolumn{2}{|l|}{ Once a day } & 31 & 52 \\
\hline & \multicolumn{2}{|l|}{ Twice a day } & 12 & 20 \\
\hline & \multicolumn{2}{|l|}{3 times a day } & 6 & 10 \\
\hline \multirow{3}{*}{$\begin{array}{l}\text { Drinks cold water in } \\
\text { excess }\end{array}$} & \multicolumn{2}{|l|}{ Yes } & 40 & 67 \\
\hline & \multicolumn{2}{|l|}{ No } & 20 & 33 \\
\hline & Poor hygiene & yes & 56 & 29 \\
\hline \multirow{4}{*}{$\begin{array}{l}\text { Do you believe the } \\
\text { following lead to } \\
\text { tonsillitis? }\end{array}$} & Malnutrition & Yes & 30 & 15 \\
\hline & Cold drinks & Yes & 53 & 27 \\
\hline & Weather change & Yes & 50 & 26 \\
\hline & I don't know & & 5 & 3 \\
\hline \multirow{2}{*}{$\begin{array}{l}\text { Do you believe } \\
\text { tonsillitis is a severe } \\
\text { disease? }\end{array}$} & \multicolumn{2}{|l|}{ Yes } & 10 & 17 \\
\hline & \multicolumn{2}{|l|}{ No } & 50 & 83 \\
\hline
\end{tabular}


Table 3. Factors that influence tonsillitis.

\begin{tabular}{|c|c|c|c|}
\hline Variable & & Frequency & Percentage \\
\hline \multirow{2}{*}{$\begin{array}{l}\text { Family history of } \\
\text { tonsillitis }\end{array}$} & Yes & 49 & 82 \\
\hline & No & 11 & 18 \\
\hline \multirow{6}{*}{$\begin{array}{l}\text { Does the child have any } \\
\text { of the following } \\
\text { diseases? }\end{array}$} & Malnutrition & 6 & 10 \\
\hline & Blood cancer & 0 & 0 \\
\hline & Diabetes & 0 & 0 \\
\hline & Allergies & 3 & 5 \\
\hline & Asthma & 4 & 7 \\
\hline & None of them & 47 & 78 \\
\hline \multirow{4}{*}{$\begin{array}{l}\text { Do you believe } \\
\text { treatment is adequate? } \\
\text { Chronic rhinitis and } \\
\text { chronic sinusitis. }\end{array}$} & Yes & 18 & 30 \\
\hline & No & 42 & 70 \\
\hline & Yes & 21 & 35 \\
\hline & No & 39 & 65 \\
\hline \multirow{2}{*}{$\begin{array}{l}\text { Mouth breathing due to } \\
\text { nasal obstruction }\end{array}$} & Yes & 45 & 75 \\
\hline & No & 15 & 25 \\
\hline \multirow{2}{*}{$\begin{array}{l}\text { Adenoid hypertrophy } \\
\text { and nasopharyngitis }\end{array}$} & Yes & 13 & 22 \\
\hline & No & 47 & 78 \\
\hline \multirow{2}{*}{ Peritonsillar abscess } & Yes & 29 & 48 \\
\hline & No & 31 & 52 \\
\hline \multirow{2}{*}{ Emesis or hemorrhage? } & Yes & 10 & 17 \\
\hline & No & 50 & 83 \\
\hline \multirow{2}{*}{$\begin{array}{l}\text { Presence of other upper } \\
\text { respiratory infection }\end{array}$} & Yes & 33 & 55 \\
\hline & No & 27 & 45 \\
\hline
\end{tabular}

\section{Discussion}

It is well known that, epidemiologically, tonsillitis incidence is much higher in children, however, it is not common in children under 2 years of age [16]. Approximately $53 \%$ of the children in this study with childhood tonsillitis were 7 years old or younger. Tonsillitis in children age 5-15 is usually due to a bacterial cause, where it is mainly a viral cause in ages under 5 [16]. Studies have found Sex differences in pediatric infectious diseases and their immune responses [17, 18]. Females in this study were more affected by tonsillitis $(65 \%)$ than males $(35 \%)$. It is generally reported that childhood tonsillitis and peritonsillar abscess are more common and frequent in girls $[17,18]$ but, after the age of 14 , peritonsillar abscess becomes higher in boys [18].

We found that the study participants had lower socioeconomic status indicators: $53.3 \%$ illiterate, $55 \%$ housewives or unemployed, and $43 \%$ with a monthly family income of $\$ 200$ or less. Studies have repeatedly shown that parents' socioeconomic status significantly affects children's current health status, educational success, and their success and socioeconomic status in adulthood [13, 19-27].

It is well documented that the educational level of the parents, as well as their awareness, have a great influence on the prevention and control of childhood illnesses and the utilization of health services [25, 26]. Thus, this study found that only $17 \%$ of the caregivers believed in the severity of tonsillitis and that it could have complications. Therefore, parents' level of education is not only crucial in fully understanding the health information but also in transforming information into practices and seeking health care when needed by family members $[28,29]$.

Moreover, tonsillitis is very common among family members and can easily be transmitted [30, 31]. Our study found that $82 \%$ of the study participants had a family history of tonsillitis. In addition, only $52 \%$ of them believed the effectiveness of personal hygiene against tonsillitis. However, $52 \%$ of the caregivers reported that their children brush their teeth once a day and $17 \%$ of them reported no teeth-brushing at all. Doctors recommend and emphasize on personal hygiene since it is very effective in halting the spread and can successfully prevent tonsillitis [32].

Our study also found comorbidity of tonsillitis with malnutrition (10\%), asthma (5\%), and allergies (7\%). Children with different diseases are common in developing countries such as Somalia, however, malnutrition is among the main childhood illnesses co-occurrence reported [33-36].

Due to the convenience sampling method used in this study, the generalization of its results may be limited, however, the results are true on the study group and could give insight into the risk factors of childhood tonsillitis and set the foundations for future researches.

\section{Conclusion}

This study found that childhood tonsillitis is associated with a family history of tonsillitis, poor personal hygiene, and low socioeconomic status. We also found comorbidity of malnutrition, asthma, and allergies with tonsillitis. In the case of Somalia, a prolonged political and economic instability exacerbate the severity of infectious diseases and other childhood health issues. For effective preventive health programs, identifying factors associated with the occurrence of childhood tonsillitis is crucial in its control and prevention and to avoid further complications of the disease.

\section{Ethics Approval and Consent to Participate}

The ethical approval for this study was obtained from the Ministry of Health of Puntland and Somali Institute for Development Research and Analysis (SIDRA).

Prior to the initiation of the study, the study participants were informed about the purpose of the study and how their data will be used. Furthermore, the consent of the study participants was obtained.

\section{References}

[1] Abu Bakar M, McKimm J, Haque SZ, Majumder MAA, Haque M. Chronic tonsillitis and biofilms: a brief overview of treatment modalities. J Inflamm Res. 2018; 11: 329-37.

[2] Geißler K, Markwart R, Requardt RP, Weigel C, Schubert K, Scherag A, et al. Functional characterization of T-cells from palatine tonsils in patients with chronic tonsillitis. PLoS ONE [Internet]. 2017 Sep 6 [cited 2020 Jun 23]; 12 (9). Available from: https://www.ncbi.nlm.nih.gov/pmc/articles/PMC5587326/.

[3] Stelter K. Tonsillitis and sore throat in children. GMS Curr Top Otorhinolaryngol Head Neck Surg [Internet]. 2014 Dec 1 [cited 2020 Jun 23]; 13. Available from: https://www.ncbi.nlm.nih.gov/pmc/articles/PMC4273168/. 
[4] Georgalas CC, Tolley NS, Narula PA. Tonsillitis. BMJ Clin Evid [Internet]. 2014 Jul 22 [cited 2020 Jun 23]; 2014. Available from: https://www.ncbi.nlm.nih.gov/pmc/articles/PMC4106232/.

[5] Bhalla K, Bhardwaj P, Gupta A, Mehra S, Nehra D, Nanda S. Role of epidemiological risk factors in improving the clinical diagnosis of streptococcal sore throat in pediatric clinical practice. J Fam Med Prim Care. 2019 Oct 31; 8 (10): 3130-5.

[6] Anderson J, Paterek E. Tonsillitis. In: StatPearls [Internet]. Treasure Island (FL): StatPearls Publishing; 2020 [cited 2020 Jun 28]. Available from: http://www.ncbi.nlm.nih.gov/books/NBK544342/.

[7] Kocher J, Selby TD. Antibiotics for Sore Throat. Am Fam Physician. 2014 Jul 1; 90 (1): 23-4.

[8] Falagas ME, Mourtzoukou EG, Vardakas KZ. Sex differences in the incidence and severity of respiratory tract infections. Respir Med. 2007 Sep 1; 101 (9): 1845-63.

[9] Kvestad E, Kværner KJ, Røysamb E, Tambs K, Harris JR, Magnus P. Heritability of Recurrent Tonsillitis. Arch Otolaryngol Neck Surg. 2005 May 1; 131 (5): 383-7.

[10] Dalmar AA, Hussein AS, Walhad SA, Ibrahim AO, Abdi AA, Ali MK, et al. Rebuilding research capacity in fragile states: the case of a Somali-Swedish global health initiative. Glob Health Action. 2017; 10 (1): 1348693.

[11] Warsame A, Handuleh J, Patel P. Prioritization in Somali health system strengthening: a qualitative study. Int Health. 2016 May 1; 8 (3): 204-10.

[12] Salama F, Alwohaibi A, Alabdullatif A, Alnasser A, Hafiz Z. Knowledge, behaviours and beliefs of parents regarding the oral health of their children. Eur J Paediatr Dent. 2020 Jun; 21 (2): 103-9.

[13] Cohen S, Doyle WJ, Turner RB, Alper CM, Skoner DP. Childhood Socioeconomic Status and Host Resistance to Infectious Illness in Adulthood. Psychosom Med. 2004 Aug; 66 (4): 553-558.

[14] Weldesamuel GT, Alemayoh TT, Atalay HT, Zemichael TM. Modern health-seeking behaviour and associated factors among mothers having under 5 -years old children in Shire town, Tigray, Ethiopia: A cross-sectional study 2018. Afr J Prim Health Care Fam Med [Internet]. 2019 Aug 21 [cited 2020 Jun 28]; 11 (1). Available from: https://www.ncbi.nlm.nih.gov/pmc/articles/PMC6739541/.

[15] Akinyemi JO, Banda P, De Wet N, Akosile AE, Odimegwu $\mathrm{CO}$. Household relationships and healthcare seeking behaviour for common childhood illnesses in sub-Saharan Africa: a cross-national mixed effects analysis. BMC Health Serv Res [Internet]. 2019 May 14 [cited 2020 Jun 28]; 19. Available from: https://www.ncbi.nlm.nih.gov/pmc/articles/PMC6518738/.

[16] Tonsillitis and Peritonsillar Abscess: Practice Essentials, Background, Pathophysiology and Etiology. 2020 Apr 6 [cited 2020 Jul 2]; Available from: https://emedicine.medscape.com/article/871977-overview\#a6.

[17] Muenchhoff M, Goulder PJR. Sex Differences in Pediatric Infectious Diseases. J Infect Dis. 2014 Jul 15; 209 (Suppl 3): S120-6.
[18] Klug TE. Incidence and microbiology of peritonsillar abscess: the influence of season, age, and gender. Eur J Clin Microbiol Infect Dis. 2014 Jul 1; 33 (7): 1163-7.

[19] Bornstein MH, Hahn C-S, Suwalsky JTD, Haynes OM. Socioeconomic status, parenting, and child development: The Hollingshead Four-Factor Index of Social Status and The Socioeconomic Index of Occupations. In: Socioeconomic status, parenting, and child development. Mahwah, NJ, US: Lawrence Erlbaum Associates Publishers; 2003. p. 29-82. (Monographs in parenting series).

[20] Zurriaga O, Martínez-Beneito MA, Abellán JJ, Carda C. Assessing the social class of children from parental information to study possible social inequalities in health outcomes. Ann Epidemiol. 2004 Jul 1; 14 (6): 378-84.

[21] Currie CE, Elton RA, Todd J, Platt S. Indicators of socioeconomic status for adolescents: the WHO Health Behaviour in School-aged Children Survey. Health Educ Res. 1997 Sep 1; 12 (3): 385-97.

[22] Currie J, Goodman J. Chapter 18 - Parental socioeconomic status, child health, and human capital. In: Bradley S, Green C, editors. The Economics of Education (Second Edition) [Internet]. Academic Press; 2020 [cited 2020 Jul 4]. p. 239-48. Available from: http://www.sciencedirect.com/science/article/pii/B978012815 3918000185 .

[23] Currie J. Healthy, Wealthy, and Wise: Socioeconomic Status, Poor Health in Childhood, and Human Capital Development. J Econ Lit. 2009 Mar; 47 (1): 87-122.

[24] Currie J, Stabile M. Socioeconomic Status and Health: Why is the Relationship Stronger for Older Children? [Internet]. National Bureau of Economic Research; 2002 Aug [cited 2020 Jul 4]. (Working Paper Series). Report No.: 9098. Available from: http://www.nber.org/papers/w9098.

[25] Sonego M, Llácer A, Galán I, Simón F. The influence of parental education on child mental health in Spain. Qual Life Res. 2013 Feb 1; 22 (1): 203-11.

[26] Saldūnaitè K, Bendoraitienè EA, Slabšinskienè E, Vasiliauskienè I, Andruškevičienè V, Zūbienè J. The role of parental education and socioeconomic status in dental caries prevention among Lithuanian children. Medicina (Mex). 2014 Jan 1; 50 (3): 156-61.

[27] Blane D. Social determinants of health--socioeconomic status, social class, and ethnicity. Am J Public Health. 1995 Jul; 85 (7): $903-5$.

[28] Monheit AC, Grafova IB. Education and family health care spending. South Econ J. 2018; 85 (1): 71-92.

[29] Dubow EF, Boxer P, Huesmann LR. Long-term Effects of Parents' Education on Children's Educational and Occupational Success: Mediation by Family Interactions, Child Aggression, and Teenage Aspirations. Merrill-Palmer Q Wayne State Univ Press. 2009 Jul; 55 (3): 224-49.

[30] Khasanov SA, Asrorov AA, Vokhidov UN. [Prevalence of chronic family tonsillitis and its prevention]. Vestn Otorinolaringol. 2006; (4): 38-40.

[31] Bager P, Corn G, Wohlfahrt J, Boyd HA, Feenstra B, Melbye M. Familial aggregation of tonsillectomy in early childhood and adolescence. Clin Epidemiol. 2018 Jan 12; 10: 97-105. 
[32] Tonsillitis - Symptoms and causes [Internet]. Mayo Clinic. [cited 2020 Jul 6]. Available from: https://www.mayoclinic.org/diseases-

conditions/tonsillitis/symptoms-causes/syc-20378479.

[33] Nordstrand MA, Saxe DS, Mohammed MA, Adam MB. Health and disease among Somali primary school children in Hargeisa. Glob Health Action [Internet]. 2019 Apr 23 [cited 2020 Jun 28]; 12 (1). Available from: https:/www.ncbi.nlm.nih.gov/pmc/articles/PMC6493321/.

[34] Kinyoki DK, Kandala N-B, Manda SO, Krainski ET, Fuglstad G-A, Moloney GM, et al. Assessing comorbidity and correlates of wasting and stunting among children in Somalia using cross-sectional household surveys: 2007 to 2010 . BMJ Open. 2016 Mar 1; 6 (3): e009854.

[35] Kinyoki DK, Moloney GM, Uthman OA, Odundo EO, Kandala N-B, Noor AM, et al. Co-morbidity of malnutrition with falciparum malaria parasitaemia among children under the aged 6-59 months in Somalia: a geostatistical analysis. Infect Dis Poverty. 2018 Jul 6; 7 (1): 72.

[36] Kinyoki DK, Manda SO, Moloney GM, Odundo EO, Berkley JA, Noor AM, et al. Modelling the Ecological Comorbidity of Acute Respiratory Infection, Diarrhoea and Stunting among Children Under the Age of 5 Years in Somalia. Int Stat Rev. 2017; 85 (1): 164-76. 